\title{
Analysis of the influence of variation factors on electrical conductivity of milk in Murciano-Granadina goats
}

\author{
J. R. Diaz, ${ }^{* 1}$ G. Romero, ${ }^{*}$ R. Muelas, ${ }^{*}$ E. Sendra, ${ }^{*}$ J. C. F. Pantoja, $†$ and C. Paredes $\ddagger$ \\ *Departamento de Tecnología Agroalimentaria, Escuela Politécnica Superior de Orihuela, Universidad Miguel Hernández, \\ Ctra. Beniel Km 3,2, 03312 Orihuela, Spain \\ †Dairy Science Department, University of Wisconsin-Madison, Madison 53706 \\ ‡Departamento de Agroquímica y Medio Ambiente, Escuela Politécnica Superior de Orihuela, Universidad Miguel Hernández, \\ Ctra. Beniel Km 3,2, 03312 Orihuela, Spain
}

\section{ABSTRACT}

The aim of this study was to obtain further knowledge on electrical conductivity (EC) of milk as a tool for detecting mastitis in goats. The effect of farm, parity, stage of lactation, and health status of the glands on EC, and the somatic cell count (SCC) of milk was analyzed. Additionally, relationships between EC and chemical composition and SCC were studied. Finally, characteristics of EC and SCC (sensitivity and specificity) as diagnostic tests used to detect mastitis were studied. One hundred and five Murciano-Granadina goats were enrolled in the study. Milk samples (by gland) were collected monthly for 7 mo on 3 farms in the southeastern Spain. To establish the health status, milk samples were aseptically collected before milking by gland. Foremilk (by gland) was collected to analyze EC, SCC, and chemical composition. Glands were classified according to the health status as free of mastitis, bacterial mastitis, or unspecific mastitis. The effects of farm, parity, and stage of lactation, as well as the interactions between health status and parity, parity and stage of lactation, and health status and stage of lactation were associated with EC. Changes in the milk's chemical composition (particularly of chloride ions) explained most of the variance in $\mathrm{EC}\left(\mathrm{R}^{2}=0.91\right)$. The strongest association between EC and SCC was found at $\mathrm{SCC}>2 \times 10^{6}$ cells $/ \mathrm{mL}(\mathrm{r}=0.42)$. The use of a single EC threshold for all animals and farms for detecting mastitis led to limited results for mastitis detection, which, in any case, favors negative predictive values over positive predictive values. This study revealed that factors, other than the health status, affecting EC hamper the use of an EC threshold for mastitis detection with sufficient specificity on all animals. Any detection system based on EC of milk should consider

Received January 18, 2011.

Accepted April 21, 2011

${ }^{1}$ Corresponding author: jr.diaz@umh.es these factors, as well as specific variations for each of the animals.

Key words: electrical conductivity, goat milk, mastitis

\section{INTRODUCTION}

In the livestock market, economic losses caused by mastitis in goats are due to a decrease in milk production (Ying et al., 2004) of the affected animals, decrease in cheese yield (Leitner et al., 2004a), and treatment costs (labor and drugs). The extent of the damage depends on a variety of factors, such as etiology of the infection, condition of the animal immune system, and duration of the infection (Corrales et al., 1996). The development of techniques for early detection of mastitis in the farm would allow rapid management of the disease, which would decrease the negative effect on milk quality and safety and on the livestock market economy.

Automatic measurements of electrical conductivity (EC) in milking systems have been studied in cattle, providing good sensitivity and specificity results (100 and 95\%, de Mol et al., 1999; 88 and 97\%, Mele et al., 2001; 92 and 93\%, Cavero et al., 2006; respectively); this is useful for detecting the disease, particularly in its clinical presentation. In this type of mastitis, early detection is of great relevance, as the disease causes important decrease in milk yield (MY), changes in milk composition, and is a risk in terms of food safety. In goats, published studies on the effect of mastitis on EC are scarce. The results of Ying et al. (2004) in studies with different races of goats were contradictory. They observed that EC increased with infection in Saanen goats (from $5.6 \mathrm{mS} / \mathrm{cm}$ in healthy animals to $5.8 \mathrm{mS}$ / $\mathrm{cm}$ in infected ones), whereas for Alpine goats the EC decreased (from $6.1 \mathrm{mS} / \mathrm{cm}$ for healthy goats to 5.4 $\mathrm{mS} / \mathrm{cm}$ in infected ones). Thus, the possibility of using this diagnostic test as a method for detecting mastitis in milk-producing goats will be analyzed; consequently, it is necessary to gain further knowledge on the be- 
havior of the variable (infection-unrelated factors that could have an effect on EC) and the possibilities of its application.

Aside from mastitis, other animal-related extrinsic and intrinsic factors can affect EC in cattle: the animal per se, breed, stage of lactation, heat, parity, diet, intervals between milking, and even the analyzed milk fraction, are factors that affect the composition of the milk, and consequently, its EC (Hamann and Zecconi, 1998).

This study aims to obtain further insight on EC of milk as a tool for detecting mastitis in goats. For this, factors affecting EC were studied as a first step to establish a useful threshold with enough sensitivity and specificity for mastitis in goats. Additionally, the relationships between EC and SCC and between EC and composition were studied.

\section{MATERIALS AND METHODS}

\section{Participating Farms and Animal Management}

The experiment was carried out in 3 different farms: 2 commercial (farm 1: 250 goats; farm 2: 800 goats) and the educational farm of the Universidad Miguel Hernández (farm 3: 200 goats). All farms were part of the Spanish Association of Murciano-Granadina Goat Breeders (ACRIMUR), located in southeastern Spain. Farms were characterized by intensive management of the animals, permanent stabling, one parturition per year, artificial feeding from birth, and mechanical milking once a day (in the morning). The milking parlors used were low-line Casse type with self-locking gates, designed as follows (number of platforms $\times$ number of places/platform $\times$ number of milking units/platform): $1 \times 12 \times 6$ in farm $1,2 \times 24 \times 24$ in farm 2 , and $1 \times$ $12 \times 12$ in farm 3 .

\section{Experimental Design and Studied Variables}

Data Collection. One hundred and five (36 from farm 1, 45 from farm 2, and 24 from farm 3) animals were chosen, considering parity (primiparous or multiparous), MY ( $2 \pm 0.1 \mathrm{~L})$, and health status (HS) of the mammary glands at the beginning of lactation (bacteriological identification of mastitis pathogens and SCC analysis were both carried out at 7 and $15 \mathrm{~d}$ after parturition for selection of animals).

Farms were visited monthly for data collection for a total of 7 mo. On farm 2 and farm 3, all of the studied variables were analyzed in mo 1 to 7 . For farm 1 , samples for mo 6 were not processed due to a problem during their transportation to the laboratory; thus, only 6 farm visits were performed.
For each farm visit, collection of milk samples was done before mechanical milking by hand; 2 samples were taken from each gland. The first sample $(5 \mathrm{~mL})$ was obtained aseptically, from teats carefully cleaned with $70 \%$ ethanol, discarding the first 3 streams of foremilk and placed into sterile tubes; these were used for the bacteriological analysis and afterward kept frozen until the end of the experiment. In addition, another $100 \mathrm{~mL}$ of milk per gland was drawn for the remaining analyses: EC, SCC, macro-composition (fat, CN, whey protein, ash, and lactose), and mineral content (chlorides, sodium, potassium, calcium, phosphorous).

Definition of Health Status of the Gland. To determine the HS of the gland, both bacteriological analysis and SCC results were considered. A gland was defined as having bacterial mastitis (BAC) when bacteriological analyses were positive for IMI. When the bacteriological analysis was negative and SCC was $>1,000,000$ cells $/ \mathrm{mL}$ on 2 or more consecutive sampling days and for non-physiological causes, it was considered as unspecific (UNS). A physiologic increase in SCC (for example, due to estrus; Christodoulopoulos et al., 2008) was defined when bacteriological analysis was negative and an increase of SCC occurred in both glands in an isolated analysis that was followed by $\mathrm{SCC}<1,000,000$ cells $/ \mathrm{mL}$ in a subsequent analysis, or end of lactation occurred. A gland was considered free from mastitis with negative bacterial culture and if the increase of SCC values was due to physiological causes.

Variables and Laboratory Methods. Milk samples for bacteriological analysis were kept at $4^{\circ} \mathrm{C}$ for a maximum of $12 \mathrm{~h}$ until analysis. Twenty microliters of each sample was plated on blood agar plates (5\% washed sheep erythrocytes; bioMérieux, Lyon, France). The plates were incubated aerobically at $37^{\circ} \mathrm{C}$ and examined at 24, 48 and $72 \mathrm{~h}$. Cultures with 5 or more identical colonies were considered positive for IMI. Bacteria were identified according to the National Mastitis Council recommendations (Harmon et al., 1990).

Electrical conductivity of milk $(\mathrm{mS} / \mathrm{cm})$ was a continuous variable measured with a laboratory conductimeter (GLP 32; Crison Instruments, Alella, Spain) and automatic temperature compensation to $25^{\circ} \mathrm{C}$.

SCC $(\times 1,000$ cells $/ \mathrm{mL})$ was a continuous variable analyzed with electronic cell counter (Fossomatic 90; Foss Electric, Hillerød, Denmark) using 30-mL aliquots of milk preserved with azidiol.

Chemical composition (fat, CN, whey protein, ash, and lactose) was analyzed using near-infrared spectroscopy (NIRS; InfraAlyzer 500; Bran+Luebbe GmbH, Norderstedt, Germany) for samples collected on farm 1 (visits 1, 3, 5, and 7) and farm 2 (all visits). Results were expressed as grams per 100 grams of milk. 
Mineral composition was determined on visits 1,2 , 3,5 , and 6 for farm 2 , from a selection of 22 animals: 7 goats for which no mastitis was detected during the whole study ( 6 primiparous and 1 multiparous), 6 with unilateral mastitis (5 primiparous and 1 multiparous), 9 with bilateral mastitis ( 3 primiparous and 6 multiparous). Chloride content $(\mathrm{mg} / \mathrm{L})$ was analyzed using the Mohr method adapted to milk (AOAC, 1995). Sodium and potassium contents $(\mathrm{mg} / \mathrm{L})$ were analyzed by flame photometry (PFP; Jenway, Staffordshire, UK). Total calcium content $(\mathrm{mg} / \mathrm{L})$ was analyzed using an atomic absorption flame spectrophotometer [Unicam 969 AA; International Dairy Federation (IDF) standard 154; IDF, 1992]. Total phosphorous content $(\mathrm{mg} / \mathrm{L})$ was analyzed using an atomic absorption spectrophotometer (model 8453; Hewlett-Packard Co., Palo Alto, CA; IDF standard 42B; IDF, 1990).

Determination of MY of glands was only possible in the educational and experimental farm (farm 3) and was performed using electronic measurement devices (Metatron; GEA WestfaliaSurge GmbH, Bönen, Germany).

\section{Statistical Analysis}

First, the distribution of variables was analyzed using box plots, histograms, and normal probability plots. Values of EC $(\mathrm{mS} / \mathrm{cm})$ and SCC $(\times 1,000$ cells $/ \mathrm{mL})$ were transformed into base-10 logarithms to normalize their distributions.

The association between the explanatory variables and EC was assessed using a stepwise linear mixed model procedure. Variables that were associated with $\mathrm{EC}$ at a $P$-value $<0.05$ and first-order interaction terms were included in the final model (PROC MIXED, version 9.1; SAS Institute, 2002); it included EC as outcome variable and the following explanatory variables: farm (3 levels: farm 1, farm 2, and farm 3); HS (3 levels: mastitis-free, BAC, and UNS); stage of lactation (7 levels: mo 1, mo 2, . ., mo 7 ); parity (2 levels: primiparous and multiparous); the interaction between parity and stage of lactation; the interactions between stage of lactation and health status; and the interaction between health status and parity. To account for the clustering of mammary glands within animals (Barkema et al., 1997), goat was considered a random term. In addition, an unstructured covariance structure was used to account for the repeated measurements over time on the same mammary glands. The model using this hierarchical structure provided the best fit for the data when compared with different models considering other covariance and hierarchical structures (as assessed using Bayesian and Akaike's information criteria).
A similar modeling procedure was used to assess the association between SCC and selected explanatory variables. As a result, the final model included SCC as the outcome variable and the following explanatory variables: farm (3 levels: farm 1, farm 2 , and farm 3 ); HS (3 levels: mastitis-free, BAC, and UNS); stage of lactation (7 levels: mo 1 to 7 ); and parity (2 levels: primiparous and multiparous).

Two linear regression models were used to study the relationship between EC and the chemical composition of the milk (PROC REG, version 9.1; SAS Institute, 2002). Regression 1 was carried out, considering as independent variables only those of the macro-composition data analyzed from farm 1 and farm 2 (fat, CN, whey proteins, NPN, lactose, and ash). Regression 2 was carried out, considering as independent variables data of macro-composition and mineral content (fat, $\mathrm{CN}$, whey proteins, lactose, chlorides, sodium, potassium, calcium, and phosphorous) from farm 2.

The relationship between EC and SCC was studied using the Spearman coefficient of correlation for each HS in the glands (PROC CORR, version 9.1; SAS Institute, 2002), using 5 levels of SCC (SCC $\leq 500,000$; $500,000<\mathrm{SCC} \leq 1,000,000 ; 1,000,000<\mathrm{SCC} \leq$ $1,500,000 ; 1,500,000<\mathrm{SCC} \leq 2,000,000 ;$ and $\mathrm{SCC}>$ $2,000,000$ cells $/ \mathrm{mL}$ ).

The relationship between EC and MY in the glands in farm 3 (where MY was measured by gland) was studied using the Spearman coefficient of correlation, according to their HS (PROC CORR, version 9.1; SAS Institute, 2002).

Diagnostic test characteristics of EC and SCC to detect mastitis (both BAC and UNS) were estimated using various thresholds. Sensitivity was defined as the probability of a truly infected mammary gland (BAC or UNS) to be classified as test positive. Specificity was defined as the probability of a negative sample (mastitis-free) to be classified as such. Additionally, for every threshold, the positive predictive value (PPV) was calculated and defined as the probability of the gland to be truly infected (BAC or UNS) when the sample was classified as positive, as well as the negative predictive value (NPV), defined as the probability of the gland not being infected (mastitis-free) when the sample was classified as negative.

\section{RESULTS}

\section{Incidence and Prevalence of Mastitis}

At the beginning of the study, $77.3 \%$ of the glands included in the study were mastitis-free, $11.8 \%$ had BAC, and $10.9 \%$ had UNS (global prevalence of mastitis: $22.7 \%$; Table 1 ). 
Table 1. Distribution (no.) of glands at the beginning of the study by farm, parity (NL), ${ }^{1}$ and health status

\begin{tabular}{|c|c|c|c|c|c|c|c|c|c|c|c|}
\hline Health status & \multicolumn{2}{|c|}{ Farm 1} & \multicolumn{3}{|c|}{ Farm 2} & \multicolumn{3}{|c|}{ Farm 3} & \multicolumn{3}{|c|}{ Total } \\
\hline $\begin{array}{l}\text { Free of mastitis } \\
\text { Unilateral mastitis }\end{array}$ & 54 & $54(75.0)$ & 32 & 33 & $65(72.2)$ & 18 & 25 & $43(89.6)$ & 50 & 112 & $162(77.3)$ \\
\hline Bacterial & 1 & $1(1.4)$ & 3 & 4 & $7(7.8)$ & 2 & 3 & $5(10.4)$ & 5 & 8 & $13(6.1)$ \\
\hline Unspecific & 1 & $1(1.4)$ & 3 & 1 & $4(4.4)$ & 0 & 0 & 0 & 3 & 2 & $5(2.3)$ \\
\hline Bilateral mastitis & & & & & & & & & & & \\
\hline Total & 72 & $72(100.0)$ & 42 & 48 & $90(100.0)$ & 20 & 28 & $48(100.0)$ & 62 & 148 & $210(100.0)$ \\
\hline
\end{tabular}

${ }^{1} \mathrm{NL}>1$ : multiparous; $\mathrm{NL}=1$ : primiparous.

${ }^{2}$ Percents are given in parentheses.

During the study, the maximum prevalence of mastitis in farm 1, farm 2, and farm 3, respectively, was 52.7, 75.5 , and $62.5 \%$ in the animals (number of infected animals/total animals) and 48.6, 70.0, and $37.5 \%$ in the glands (number of infected mammary glands/total glands). The overall prevalence of mastitis in the study was $64.8 \%$ in the animals and $55.2 \%$ in the glands. The incidence of mastitis (number of new mastitis cases/ number healthy at the beginning of the study) for farm 1 , farm 2, and farm 3, respectively, was 34.6, 59.3, and $52.6 \%$, in the animals, and $31.5,58.5$, and $30.2 \%$ in the glands (overall incidence: $48.6 \%$ in the animals and $41.9 \%$ in the glands). In farm 1, a cure (gland classified as BAC or UNS in the previous analysis that became mastitis-free in the analysis after) of 8 glands 4 goats occurred; in farm 2, 9 glands/8 goats; and in farm 3, 3 glands/ 3 goats. Thus, at the end of the study (mo 7 of lactation, Table 2), the prevalence of mastitis was lower than at the maximum prevalence of mastitis $(41.6,73.3$, and $50 \%$, for the animals and $37.5,60.0$, and $43.7 \%$, for the glands in farm 1 , farm 2 , and farm 3 , respectively).

\section{Factors Associated with EC and SCC of Milk}

Farm, parity, stage of lactation, HS, the interaction between parity and stage of lactation, the interaction between parity and HS, and the interaction between stage of lactation and HS remained in the final model with EC as an outcome variable (Table 3). For SCC, all considered factors (farm, stage of lactation, HS, and parity) were significant and remained in the final model with SCC as an outcome variable, the most relevant being HS (Table 3 ).

Electrical conductivity was significantly lower in farm $1(5.14 \mathrm{mS} / \mathrm{cm})$ in comparison with farm 2 and farm 3 (5.79 and $5.78 \mathrm{mS} / \mathrm{cm}$, respectively), whereas SCC was significantly higher in farm $2\left(1,294 \times 10^{3}\right.$ cells $\left./ \mathrm{mL}\right)$ in comparison with farm 1 and farm $3\left(630 \times 10^{3}\right.$ and 796 $\times 10^{3}$ cells $/ \mathrm{mL}$, respectively; Table 4$)$.

Means of EC in mastitis-free glands were 5.01, 5.67, and $5.63 \mathrm{mS} / \mathrm{cm}$ in farm 1 , farm 2 , and farm 3 , respectively. The interaction between farm and HS was not significant (as was mentioned in Statistical Analysis). Moreover, the highest EC was observed for UNS (5.41 $\mathrm{mS} / \mathrm{cm}$ in farm 1 and $5.95 \mathrm{mS} / \mathrm{cm}$ in farm 2), whereas the lowest was observed in cases of $\operatorname{BAC}(5.09,5.69$, and $5.73 \mathrm{mS} / \mathrm{cm}$ in farm 1 , farm 2 , and farm 3 , respectively).

An increase of EC occurred with progression of lactation at 3 different phases: lowest values at mo 1, higher values at mo 2 to 6 , and highest values at mo 7 . For SCC, 2 phases of progression occurred: lowest values

Table 2. Distribution (no.) of glands by farm, health status, and parity (NL) $)^{1}$ at the end of the study

\begin{tabular}{|c|c|c|c|c|c|c|c|c|c|c|c|}
\hline Health status & \multicolumn{2}{|c|}{ Farm 1} & \multicolumn{3}{|c|}{ Farm 2} & \multicolumn{3}{|c|}{ Farm 3} & \multicolumn{3}{|c|}{ Total $^{2}$} \\
\hline $\begin{array}{l}\text { Free of mastitis } \\
\text { Unilateral mastitis }\end{array}$ & 45 & 45 & 25 & 11 & 36 & 18 & 15 & 33 & $43(-7)$ & $71(-41)$ & $114(-48)$ \\
\hline Bacterial & 2 & 2 & 6 & 5 & 11 & 2 & 5 & 7 & $8(+3)$ & $12(+4)$ & $20(+7)$ \\
\hline Unspecific & 1 & 1 & 1 & 0 & 1 & 0 & 0 & 0 & $1(-2)$ & $1(-1)$ & $2(-3)$ \\
\hline Bilateral mastitis & & & & & & & & & & & \\
\hline
\end{tabular}

${ }^{1} \mathrm{NL}>1$ : multiparous; $\mathrm{NL}=1$ : primiparous.

${ }^{2}$ Values in parentheses are the number of glands increased relative to that at the beginning of the study. 
Table 3. Results of statistical analysis ( $F$-value and significance level) of electrical conductivity (EC) and SCC in goat milk from glands

\begin{tabular}{lcr}
\hline Effect & LEC $^{1}$ & \multicolumn{1}{c}{ LSCC $^{2}$} \\
\hline Farm & $20.63^{* * *}$ & $8.14^{* *}$ \\
Parity & $6.96^{* *}$ & $27.34^{* * *}$ \\
Stage of lactation & $4.35^{* * *}$ & $4.57^{* * *}$ \\
Health status & $15.18^{* * *}$ & $136.63^{* * *}$ \\
Parity $\times$ stage of lactation & $12.41^{* * *}$ & \\
Parity $\times$ health status & $5.17^{* *}$ & \\
Stage of lactation $\times$ health status & $6.53^{* * *}$ & \\
\hline
\end{tabular}

${ }^{1}$ LEC: logarithm of EC; number of observations: 1,328.

${ }^{2}$ LSCC: logarithm of SCC; number of observations: 1,245.

** $P<0.01$; *** $P<0.001$.

from mo 1 to 3 , and highest values from mo 4 to 7 (Table 5).

In both primiparous and multiparous goats, the EC of glands with BAC did not differ significantly compared with the EC of mastitis-free glands. In the primiparous goats, the EC of the UNS glands increased significantly compared with the mastitis-free or BAC glands; however, this did not occur in the multiparous goats (Table 6). The EC of milk from multiparous goats was higher than that of primiparous goats with no mastitis or with BAC; no significant differences were observed with UNS.

The EC of milk from multiparous goats increased with progress of lactation, but an increase was not observed for primiparous goats (Figure 1). The EC increased with progress of lactation in mastitis-free glands, whereas in animals that suffered BAC or UNS, EC did not differ significantly over the lactation period (Figure 2).

A significant increase in SCC was determined with parity; SCC was significantly lower in milk collected from primiparous goats $(556,000$ cells/mL vs. $1,335,000$ cells $/ \mathrm{mL}$ in multiparous goats). Similarly, the HS was associated with SCC; significant differences were recorded in the 3 studied HS (UNS $=2,456,000$ cells $/ \mathrm{mL}$, $\mathrm{BAC}=826,000$ cells $/ \mathrm{mL}$, and mastitis-free $=315,000$ cells $/ \mathrm{mL}$ ).

\section{Relationship Between Electrical Conductivity and Chemical Composition, Yield, and SCC}

When only macro-composition data was included (regression 1 ), the coefficient of determination $\left(\mathrm{R}^{2}\right)$ was low (0.128; Table 7$)$; in this case, most of the variance was explained by the content of fat. When data related to mineral content was included (regression 2), a great increase in $\mathrm{R}^{2}$ was obtained (0.91); here, most of the variance was explained by the content in chlorides, in presence of which a partial $\mathrm{R}^{2}$ of 0.78 was determined, much higher than for the rest of the components (Table 8).

The correlation between MY and EC was not significant when all data were included $(\mathrm{r}=-0.103 ; P=$ 0.067). When the data were analyzed separately (i.e., according to the HS), the correlation was significant for infected glands (BAC) and a moderate correlation coefficient was obtained $(\mathrm{r}=-0.372, P=0.005)$; nevertheless, it was not significant for other mastitis-free or UNS glands.

A significant, but moderate, correlation was observed between EC and SCC $(\mathrm{r}=0.38, P<0.001$; Table 9$)$, increasing with higher $\mathrm{SCC}$ values; maximum coefficient was reached at SCC $>2,000,000$ cells $/ \mathrm{mL}(\mathrm{r}=$ 0.38). When HS was considered, the highest correlation coefficient was observed in milk collected from UNS glands with $\mathrm{SCC}>2,000,000$ cells $/ \mathrm{mL}(\mathrm{r}=0.42)$.

\section{Detection of Mastitis According to EC and SCC Behavior}

Sensitivity and specificity (Figure 3), PPV, and NPV values (Figure 4) for EC for detecting mastitis varied according to the analyzed farm. Higher values of sensitivity were obtained at farm 3 , being lower at farm 1 . At higher thresholds of EC, the sensitivity was lower and the NPV decreased, due to the higher number of false negatives. The NPV was higher than the PPV, which indicates that this test better classified negative

Table 4. Electrical conductivity (EC) and SCC in goat milk from glands by farm

\begin{tabular}{|c|c|c|c|c|}
\hline \multirow[b]{2}{*}{ Farm } & \multicolumn{2}{|c|}{$\mathrm{LEC}^{1}$} & \multicolumn{2}{|c|}{$\mathrm{LSCC}^{2}$} \\
\hline & $\begin{array}{c}\text { Mean } \\
(\text { antilog })^{3}\end{array}$ & $\begin{array}{c}\mathrm{SE} \\
(\text { no. })\end{array}$ & $\begin{array}{c}\text { Mean } \\
(\text { antilog })^{4}\end{array}$ & $\begin{array}{c}\mathrm{SE} \\
(\text { no. })\end{array}$ \\
\hline $\begin{array}{l}\text { Farm } 1 \\
\text { Farm } 2 \\
\text { Farm } 3\end{array}$ & $\begin{array}{l}0.7112^{\mathrm{a}}(5.14) \\
0.7626^{\mathrm{b}}(5.79) \\
0.7616^{\mathrm{b}}(5.78)\end{array}$ & $\begin{array}{l}0.0038(434) \\
0.0045(572) \\
0.0056(322)\end{array}$ & $\begin{array}{l}5.80^{\mathrm{a}}(630) \\
6.11^{\mathrm{b}}(1,294) \\
5.91^{\mathrm{a}}(796)\end{array}$ & $\begin{array}{l}0.06(362) \\
0.05(566) \\
0.06(317)\end{array}$ \\
\hline
\end{tabular}


Table 5. Electrical conductivity (EC) and SCC in goat milk from glands by stage of lactation

\begin{tabular}{|c|c|c|c|c|}
\hline \multirow[b]{2}{*}{$\begin{array}{l}\text { Month } \\
\text { of lactation }\end{array}$} & \multicolumn{2}{|c|}{$\mathrm{LEC}^{1}$} & \multicolumn{2}{|c|}{$\mathrm{LSCC}^{2}$} \\
\hline & $\begin{array}{c}\text { Mean } \\
(\text { antilog) })^{3}\end{array}$ & $\begin{array}{l}\mathrm{SE} \\
\text { (no.) }\end{array}$ & $\begin{array}{c}\text { Mean } \\
(\text { antilog) }\end{array}$ & $\begin{array}{l}\mathrm{SE} \\
\text { (no.) }\end{array}$ \\
\hline 1 & $0.7317^{\mathrm{a}}(5.39)$ & $0.0057(208)$ & $5.83^{\mathrm{a}}(683)$ & 0.06 \\
\hline 2 & $0.7433^{\mathrm{b}}(5.54)$ & $0.0052(202)$ & $5.84^{\mathrm{a}}(688)$ & $0.05(200)$ \\
\hline 3 & $0.7459^{\mathrm{bc}}(5.57)$ & $0.0048(208)$ & $5.89^{\mathrm{a}}(775)$ & $0.05(207)$ \\
\hline 4 & $0.7467^{\text {bc }}(5.58)$ & $0.0046(206)$ & $5.99^{\mathrm{b}}(984)$ & $0.05(206)$ \\
\hline 5 & $0.7516^{\text {bd }}(5.64)$ & $0.0047(210)$ & $5.97^{\mathrm{b}}(927)$ & $0.05(210)$ \\
\hline 6 & $0.7409^{\mathrm{ac}}(5.51)$ & $0.0053(122)$ & $5.99^{\mathrm{b}}(990)$ & $0.05(119)$ \\
\hline 7 & $0.7557^{\mathrm{d}}(5.69)$ & $0.0049(172)$ & $6.03^{\mathrm{b}}(1,072)$ & $0.05(165)$ \\
\hline
\end{tabular}

samples than positive ones; PPV was slightly higher in farm 1 and farm 2, in comparison to the ones obtained for farm 3, for which it was very low.

Sensitivity, specificity, PPV, and NPV values for SCC for the detection of mastitis also varied, depending on the analyzed farm (Figures 5 and 6 ), in a way that is similar to what was observed for EC; the results for SCC were more favorable.

\section{DISCUSSION}

The several variables and factors related significantly to EC indicate the complexity of its variation. Globally, it implies that factors that affect milk composition will affect milk EC.

The $F$-value results of the studied factors were different for EC and SCC. Farm was the main factor related to EC (highest $F$-value); medium $F$-values were obtained for HS and the interaction of parity with stage of lactation; parity, stage of lactation, and their interac-

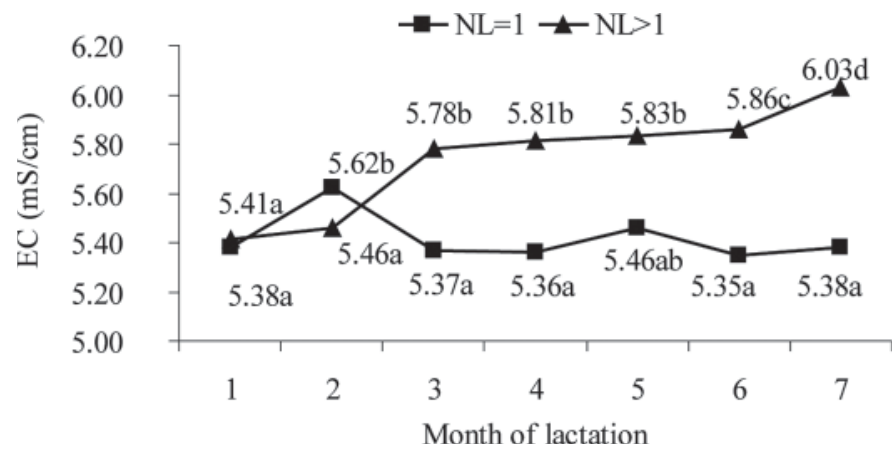

Figure 1. Effect of interaction of stage of lactation and parity (NL) on electrical conductivity (EC, antilog) of goat milk from glands. a-d: means within a line with different letters $\operatorname{differ}(P<0.05)$; NL $=1$ : primiparous; NL >1: multiparous. tions with HS had the lowest $F$-values. For SCC, the highest $F$-value was obtained for HS; medium values were obtained for parity, and the lowest values were obtained for farm and stage of lactation. These results indicate the systems that cause the variation of both variables are different.

The variable farm covers various aspects related to the management and feeding of the animals. The lack of differences between 2 farms could be explained by the closeness of them and their similar management and feeding. The lack of interaction of the farm with the other factors implies that the results observed for other factors will occur at any farm. Feeding and management are the main variations in the farm factor causing variation of milk composition in all glands and animals, and thus, in milk EC (Hamann and Zecconi, 1998).

The presence of UNS caused an increase of EC in glands of primiparous goats, although this increase was not significant in multiparous goats, due to the higher EC at mastitis-free and BAC levels. Ying et al. (2004)

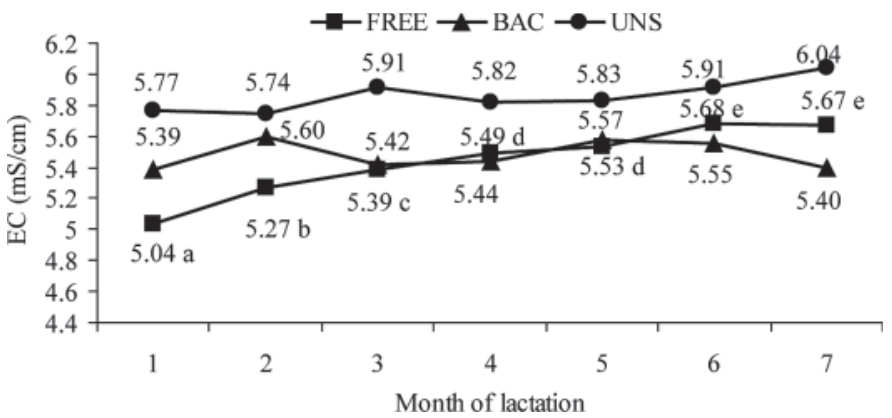

Figure 2. Effect of interaction of stage of lactation and health status on electrical conductivity (EC, antilog) of goat milk from glands. a-e: means within a line with different letters differ $(P<0.05)$; FREE: without mastitis; BAC: bacteriological infected; UNS: unspecific mastitis. 
Table 6. Electrical conductivity (EC) in goat milk from glands by parity and health status

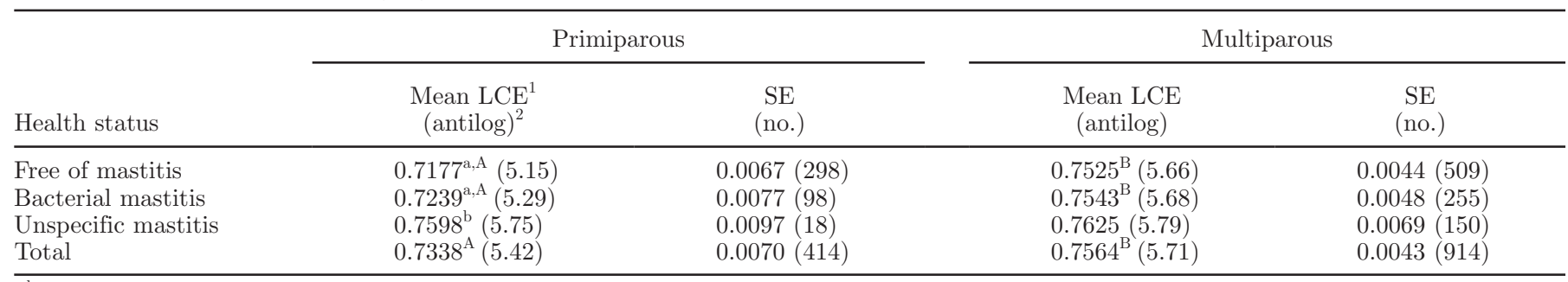

${ }^{\mathrm{a}, \mathrm{b}}$ Means within a column with different lowercase superscripts differ $(P<0.05)$.

${ }^{\mathrm{A}, \mathrm{B}}$ Means within a row with different uppercase superscripts differ $(P<0.05)$.

${ }^{1}$ LEC: logarithm of EC.

${ }^{2}$ Antilog: antilogarithm $(\mathrm{mS} / \mathrm{cm})$.

Table 7. Macro-composition variables related to electrical conductivity of goat milk from glands selected in regression 1

\begin{tabular}{lcccccc}
\hline & \multicolumn{5}{c}{ Variable $^{1}$} & \multirow{2}{*}{ Model } \\
\cline { 2 - 5 } Statistic & Intercept & Fat (\%) & WP (\%) & LAC (\%) & Ash (\%) & W. \\
\hline Parameter & 0.7354 & -0.01455 & -0.04706 & -0.0113 & 0.13071 & $778^{2}$ \\
SE & 0.0260 & 0.0017 & 0.0148 & 0.0030 & 0.0255 & $28.49^{3 * * *}$ \\
$\mathrm{R}^{2}$ partial & & 0.0643 & 0.0114 & 0.0299 & 0.0230 & $0.1285^{4}$ \\
\hline
\end{tabular}

${ }^{1}$ WP: whey protein; LAC: lactose. Variables included in the model: fat, CN, WP, LAC, and ash.

${ }^{2}$ Number of observations.

${ }^{3} \mathrm{~F}$-value.

${ }^{4}$ Coefficient of determination.

*** $P<0.001$.

Table 8. Macro-composition and mineral variables related to electrical conductivity of goat milk from glands selected by regression 2

\begin{tabular}{lcccccccc}
\hline & \multicolumn{9}{c}{ Variable $^{1}$} \\
\cline { 2 - 8 } Statistic & Intercept & $\begin{array}{c}\text { Chlorine } \\
(\mathrm{mg} / \mathrm{L})\end{array}$ & $\begin{array}{c}\text { Sodium } \\
(\mathrm{mg} / \mathrm{L})\end{array}$ & $\begin{array}{c}\text { Potassium } \\
(\mathrm{mg} / \mathrm{L})\end{array}$ & $\begin{array}{c}\text { Calcium } \\
(\mathrm{mg} / \mathrm{L})\end{array}$ & $\begin{array}{c}\text { Fat } \\
(\%)\end{array}$ & $\begin{array}{c}\text { CN } \\
(\%)\end{array}$ & Model \\
\hline Parameter & 0.44078 & 0.00014 & 0.00011 & 0.00009 & -0.00002 & -0.00358 & -0.02536 & $216^{2}$ \\
$\mathrm{SE}$ & 0.02229 & 0.00001 & 0.00001 & 0.00001 & 0.00001 & 0.00116 & 0.00486 \\
$\mathrm{R}^{2}$ partial & & 0.7796 & 0.0407 & 0.0556 & 0.0079 & 0.0042 & 0.0195 \\
\hline
\end{tabular}

${ }^{1}$ Variables included in the model: fat, CN, whey protein, chlorine, sodium, potassium, calcium, and phosphorus.

${ }^{2}$ Number of observations.

${ }^{3} \mathrm{~F}$-value.

${ }^{4}$ Coefficient of determination.

*** $P<0.001$.

Table 9. Spearman correlation coefficients between electrical conductivity and SCC of goat milk from glands by health status of glands and different intervals of SCC

\begin{tabular}{|c|c|c|c|c|c|c|c|c|}
\hline $\mathrm{SCC}(\times 1,000$ cells $/ \mathrm{mL})$ & \multicolumn{6}{|c|}{ Health status } & & \\
\hline $\mathrm{SCC} \leq 500$ & $0.13^{* * *}$ & 466 & $0.31^{*}$ & 62 & -0.33 & 4 & $0.15^{* * *}$ & 532 \\
\hline $500<\mathrm{SCC}<1,000$ & $0.21^{*}$ & 136 & -0.19 & 81 & 0.57 & 8 & 0.04 & 225 \\
\hline $1,000<\mathrm{SCC} \leq 1,500$ & 0.12 & 53 & -0.08 & 46 & 0.19 & 28 & 0.04 & 127 \\
\hline Total & $0.31^{* * *}$ & 744 & $0.41^{* * *}$ & 345 & $0.49^{* * *}$ & 152 & $0.38^{* * *}$ & 1,241 \\
\hline
\end{tabular}

${ }^{*} P<0.05 ;{ }^{* * *} P<0.001$. 


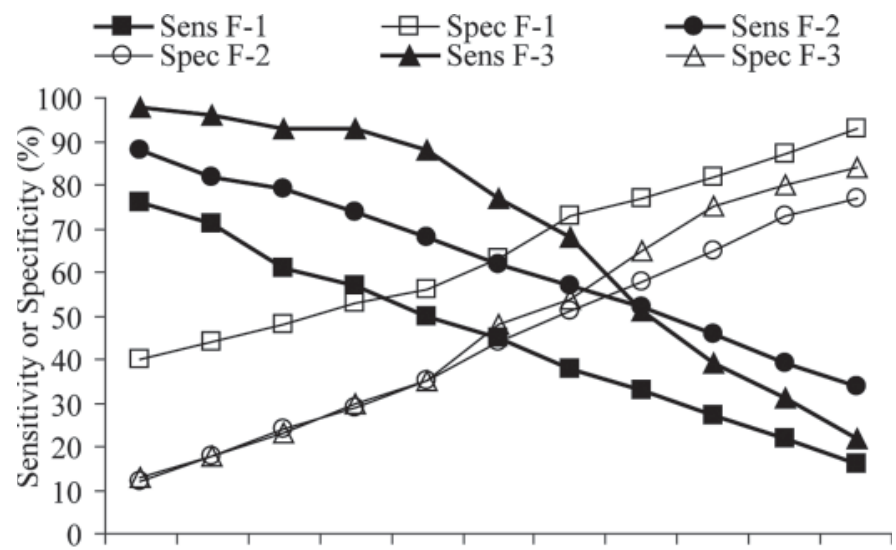

$\begin{array}{lllllllllll}5.00 & 5.10 & 5.20 & 5.30 & 5.40 & 5.50 & 5.60 & 5.70 & 5.80 & 5.90 & 6.00\end{array}$ $\mathrm{EC}(\mathrm{mS} / \mathrm{cm})$

Figure 3. Sensitivity (Sens) and Specificity (Spec) of electrical conductivity (EC) on mastitis detection by proposed EC of goat milk from gland thresholds and farm 1 (F-1), farm 2 (F-2), and farm 3 (F-3).

obtained contradictory results for 2 breeds of goats: Saanen goats increased EC due to the infection (from $5.6 \mathrm{mS} / \mathrm{cm}$ in healthy to $5.8 \mathrm{mS} / \mathrm{cm}$ in infected ones), whereas in Alpines the EC decreased (from $6.1 \mathrm{mS} / \mathrm{cm}$ in healthy to $5.4 \mathrm{mS} / \mathrm{cm}$ in infected goats). In cattle, Lien et al. (2005) determined a mean value of $5.50 \mathrm{mS} /$ $\mathrm{cm}$ in healthy quarters and $6.68 \mathrm{mS} / \mathrm{cm}$ for quarters with mastitis, although no significant differences were observed when $\log$ SCC was between 5.6 and 6 , or if the EC was measured using a representative sample collected from total milking.

Higher EC were obtained for multiparous goats compared with primiparous ones at mastitis-free and $\mathrm{BAC}$ levels of HS, being consistent with results obtained

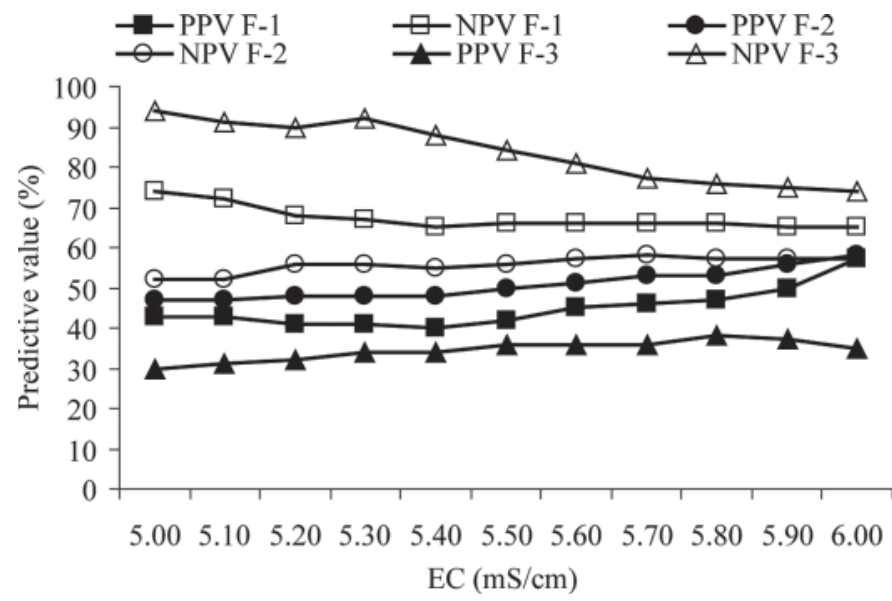

Figure 4. Positive predictive value (PPV) and negative predictive value (NPV) of electrical conductivity (EC) in mastitis detection by proposed EC of goat milk from gland thresholds and farm 1 (F-1), farm $2(\mathrm{~F}-2)$, and farm 3 (F-3).

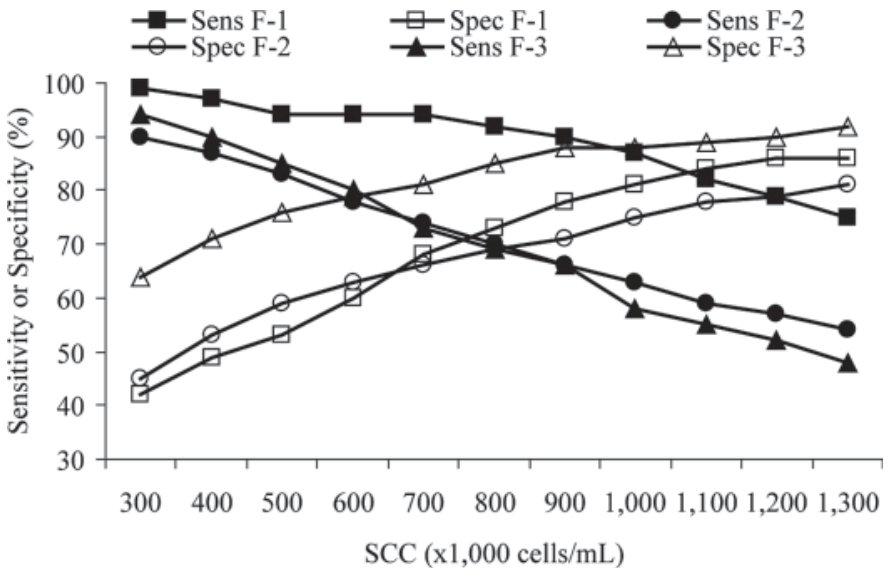

Figure 5. Sensitivity (Sens) and specificity (Spec) of SCC in mastitis detection by proposed SCC in goat milk from gland thresholds and farm 1 (F-1), farm 2 (F-2), and farm 3 (F-3).

for cows (Holdaway et al., 1996; Zecconi et al., 2004); according to these authors, it could be attributed to higher permeability of the milk-blood barrier in multiparous animals and different milk composition, because glands in these animals are more damaged due to multiple lactations.

The significant and gradual increase of EC with the progress of lactation in multiparous goats and mastitisfree glands agree with results of Holt (1985), who published an increase of $\mathrm{Na}^{+}$and $\mathrm{Cl}^{-}$concentrations in milk at the end of lactation, due to a higher transfer of these minerals from blood to milk. Changes at the end of lactation in the blood-milk barrier decrease the tightness of the mammary epithelium and increase its permeability, which can be attributed to greater damage in the gland at this stage of lactation. This agrees with

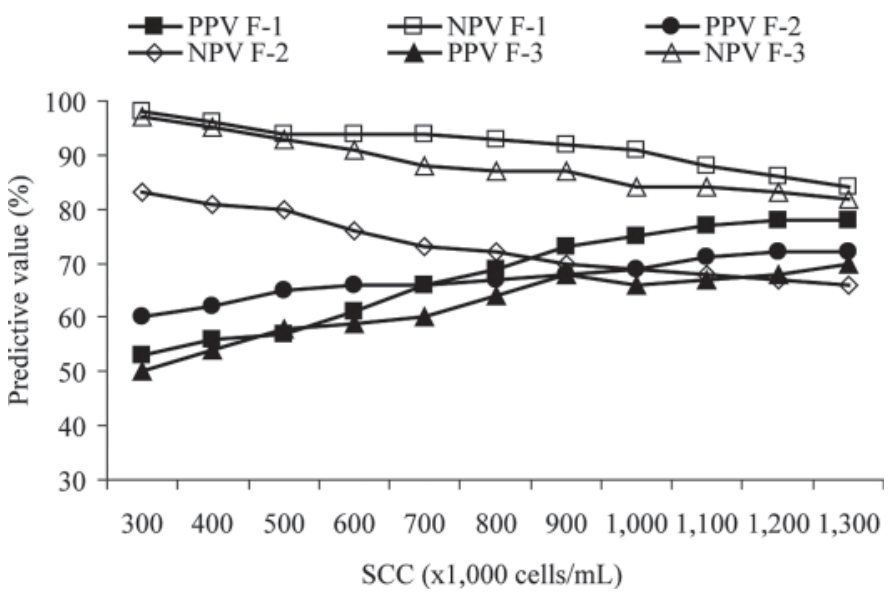

Figure 6. Positive predictive value (PPV) and negative predictive value (NPV) of SCC in mastitis detection by proposed SCC in goat milk from gland thresholds and farm 1 (F-1), farm 2 (F-2), and farm 3 (F-3). 
the results obtained in the current study from regression with composition (higher relationship with mineral content: chlorides, sodium, and potassium, compared with macro-constituents: fat, proteins, and lactose) and with those observed by Fernando et al. (1982, 1985) in cows. Hamann and Zecconi (1998) explained that dissociated inorganic salts are the main contributors of EC in milk and chlorides, sodium, and potassium are responsible for over $60 \%$ of the EC value. Fernando et al. (1985) determined a positive and high correlation between EC and chloride and sodium content in cow milk ( $\mathrm{r}=0.84$ and 0.88 , respectively). Ying et al. (2004), for Saanen goat milk, obtained a moderate relationship of EC with sodium $(\mathrm{r}=0.36)$; however, they did not obtain a significant correlation in milk from Alpine goats. The positive relationship obtained for potassium is in agreement with Ying et al. (2004) ( $\mathrm{r}=$ 0.19 for Saanen, and $\mathrm{r}=0.62$ for Alpine goats), but not with the results of Fernando et al. (1985) in cow milk (r $=-0.37$ ). Related to this, higher contents of potassium and chloride were found in milk from healthy multiparous than healthy primiparous goats (1,562 vs. 1,495 $\mathrm{mg}$ of potassium/L; 1,878 vs. $1,670 \mathrm{mg}$ of chlorides/L, respectively; our unpublished data).

If only chemical macro-composition was considered, the negative and significant relationship between lactose and EC was in line with other studies (Das and Singh, 2000; Ying et al., 2004; Bansal et al., 2005). The increase in EC has been attributed to a decrease in lactose concentration due to the presence mastitis in goats (Barros and Leitão, 1992; Leitner et al., 2004b) and related to an increase in SCC (Martí et al., 1999). The passage of $\mathrm{Cl}^{-}$from blood into the alveolar lumen, favored by the deterioration of the membranes of epithelial cells in the mammary gland, is balanced by a decrease in lactose concentration (Hamann and Zecconi, 1998); thus, the negative correlation found between lactose and EC is related to the positive correlation between EC and chlorides. The negative correlation between fat and EC are in agreement with studies on cow milk by various authors. According to Prentice (1962) and Mucchetti et al. (1994), fat globules increase the real distance during ion migration by interfering between the electrodes when measurements of EC are done; thus, EC decreases in proportion to fat concentration. For goat milk, most results indicate negative, and generally moderate to high, correlations between fat content and EC (Park, 1991, $\mathrm{r}=-0.59$; Ying et al., $2004, \mathrm{r}=-0.52$ for Saanen goats and $\mathrm{r}=-0.77$ for Alpine goats). However, in the current study, the partial coefficient of determination was low (0.0042; Table 8), which conferred higher variability to mineral content, particularly chlorides. This low relationship was also obtained when only macro-composition was considered $\left(\mathrm{R}^{2}=0.06\right.$; Table 7$)$, confirming the higher influence of mineral content in EC variability.

Parity and HS were significant for SCC. Somatic cell counts were higher in multiparous than in primiparous goats, confirming greater gland damage, probably due to their greater exposure to pathogens in previous lactations and the physiologic deterioration of the membranes of epithelial cells in the mammary gland occurring after several lactations. Somatic cell counts also increased significantly at mastitis levels, being an indicator of damage to the mammary gland caused by identified (BAC) or unidentified agents (UNS).

A medium relationship between EC and SCC was determined by the correlation analysis; the highest significant correlation coefficients were obtained when SCC $>2,000,000$ cell $/ \mathrm{mL}$, being low or nonsignificant for the rest of intervals. No bibliographic references were found about goats. Regarding cows, Yildiz et al. (2006) observed a progressive increase of EC values with increases in SCC and California Mastitis Test (CMT) results $(4.70 \mathrm{mS} / \mathrm{cm}$ for a negative value of the CMT; 5.55 and $7.42 \mathrm{mS} / \mathrm{cm}$ for CMT values of +1 and +2 , respectively). Similar to the results of the current study, Bruckmaier et al. (2004) only determined a significant increase of EC in the infected gland as compared with the healthy collateral one, when the log SCC of the infected gland was higher than 6 .

The nonsignificant correlation obtained between EC and MY reinforces the fact that milk composition and any factor related will affect EC more than the productive level of the gland.

The sensitivity and specificity of mastitis detection of EC varied between the 3 studied farms, indicating the need for different EC thresholds for the different farms; the PPV was particularly poor, which would cause a high percentage of false positives and increase unnecessary mastitis treatment costs. Considering the several variables different from HS that were related to EC (farm, parity, and stage of lactation), and the relationship of EC with chemical composition, we concluded that to obtain better results for mastitis detection, it is necessary to consider the intrinsic variation of the animal (individual and physiological), avoiding the use of an absolute threshold for all study populations. For cattle, the methods evolved to a daily measurement of EC at gland level, with encouraging results regarding specificity and sensitivity (up to $100 \%$, depending on method). The specificity and sensitivity vary depending on the used algorithm, the type of mastitis detected (subclinical or clinical), and the use of several combined variables (de Mol et al., 1999; Zecconi et al., 2004; Cavero et al., 2006, 2007). 


\section{CONCLUSIONS}

Several factors related to EC in goat milk, other than mastitis, caused limited successful results for mastitis detection when a shared EC threshold was used on all animals and farms. Further research is necessary to study the daily progress of EC in every gland, analyze the daily variation caused by the establishment of mastitis, and to test if the development of algorithms with daily EC measurements would allow acceptable results for goats, similar to those published for cattle.

\section{ACKNOWLEDGMENTS}

The study was supported by project AGL200606909 (Ministerio de Educación y Ciencia of Spain and FEDER).

\section{REFERENCES}

AOAC. 1995. Official Methods of Analysis of AOAC International. Vol. 2. 16th ed. Chapter 33. Association of Official Analytical Chemists Inc., Arlington, VA.

Bansal, B. K., J. Hamann, N. T. Grabowski, and K. B. Singh. 2005. Variation in the composition of selected milk fraction samples from healthy and mastitic quarters, and its significance for mastitis diagnosis. J. Dairy Res. 72:144-152.

Barkema, H. W., Y. H. Schukken, T. J. G. M. Lam, D. T. Galligan, M. L. Beiboer, and A. Brand. 1997. Estimation of interdependence among quarters of the bovine udder with subclinical mastitis and implications for analysis. J. Dairy Sci. 80:1592-1599.

Barros, G. C., and C. H. S. Leitão. 1992. Influencia da mastite sobre as caracteristicas fisico-químicas do leite de cabra. Pesqui. Vet. Bras. 12:45-48.

Bruckmaier, R. M., C. E. Ontsouka, and J. W. Blum. 2004. Fractionized milk composition in dairy cows with subclinical mastitis. Vet. Med. 49:283-290.

Cavero, D., K.-H. Tölle, C. Buxadé, and J. Krieter. 2006. Mastitis detection in dairy cows by application of fuzzy logic. Livest. Sci. 105:207-213.

Cavero, D., K.-H. Tölle, G. Rave, C. Buxadé, and J. Krieter. 2007. Analyzing serial data for mastitis detection by means of local regression. Livest. Sci. 110:101-110.

Christodoulopoulos, G., N. Solomakos, P. D. Katsoulos, A. Minas, and S. K. Kritas. 2008. Influence of oestrus on the heat stability and other characteristics of milk from dairy goats. J. Dairy Res. $75: 64-68$

Corrales, J. C., A. Sánchez, D. Sierra, J. C. Marco, and A. Contreras. 1996. Relationship between somatic cell counts and intramammary pathogens in goats. Pages: 89-92 in Somatic Cells and Milk of Small Ruminants-EAAP 77. R. Rubino, ed. Wageningen Academic Publishers, Wageningen, the Netherlands.

Das, M., and M. Singh. 2000. Variation in blood leucocytes, somatic cell count, yield and composition of milk of crossbred goats. Small Rumin. Res. 35:169-174.

de Mol, R. M., A. Keen, G. H. Kroeze, and J. M. F. H. Achten. 1999. Description of a detection model for oestrus and diseases in dairy cattle based on time series analysis combined with a Kalman filter. Comput. Electron. Agric. 22:171-185.

Fernando, R. S., R. B. Rindsig, and S. L. Spahr. 1982. Electrical conductivity of milk for detection of mastitis. J. Dairy Sci. 65:659 664 .
Fernando, R. S., S. Spahr, and E. H. Jaster. 1985. Comparison of electrical conductivity of milk with other indirect methods for detection of subclinical mastitis. J. Dairy Sci. 68:449-456.

Hamann, J., and A. Zecconi. 1998. Evaluation of the electrical conductivity of milk as a mastitis indicator. Pages 5-22 in Intl. Dairy Fed. Bulletin 334. Intl. Dairy Fed., Brussels, Belgium.

Harmon, R. J., R. J. Eberhart, D. E. Jasper, B. E. Langlois, and R A. Wilson. 1990. Microbiological Procedures for the Diagnosis of Bovine Udder Infection. National Mastitis Council, Arlington, VA.

Holdaway, R. J., C. W. Holmes, and I. J. Steffert. 1996. A comparison of indirect methods for diagnosis of subclinical intramammary infection in lactating dairy cows. Aust. J. Dairy Technol. 51:64-82.

Holt, C. 1985. The milk salts: Their secretion, concentrations and physical chemistry. Pages 143-181 in Developments in Dairy Chemistry. P. F. Fox, ed. Elsevier Applied Science Publishers, London, UK.

IDF (International Dairy Federation). 1990. Milk-Determination of total phosphorus content- Method using molecular absorption spectrometry. IDF standard 42B. International Dairy Federation, Brussels, Belgium.

IDF (International Dairy Federation). 1992. Milk and milk powderDetermination of calcium by atomic absorption spectrometry. IDF standard 154. International Dairy Federation, Brussels, Belgium.

Leitner, G., U. Merin, A. Glickman, L. Weisblit, O. Krifucks, A. Shwimmer, and A. Saran. 2004a. Factors influencing milk quantity and quality in Assaf sheep and goat crossbreds. South African J. Anim. Sci. 34(Suppl. 1):162-164.

Leitner, G., U. Merin, N. Silanikove, E. Ezra, M. Chaffer, N. Gollop, M. Winkler, A. Glickman, and A. Saran. 2004b. Effect of subclinical intramammary infection on somatic cell counts, NAGase activity and gross composition of goat's milk. J. Dairy Res. 71:311-315.

Lien, C. C., Y. N. Wan, and H. N. Chen. 2005. Performance evaluation of an online EC measurement system for dairy cow mastitis inspection. Int. Agric. Eng. J. 14:89-99.

Martí, A., L. Le Roux, and F. Laurent. 1999. Quality of protein in goat half-udder milk with varying somatic cell count levels. Pages 543-546 in Milking and Milk Production of Dairy Sheep and Goats-EAAP 95. F. Barillet and N.P. Zervas, ed. Wageningen Academic Publishers, Wageningen, the Netherlands.

Mele, M., P. Secchiari, A. Serra, G. Ferruzzi, F. Paoletti, and M. Biagioni. 2001. Application of the 'tracking signal' method to the monitoring of udder health and oestrus in dairy cows. Livest. Prod. Sci. 72:279-284.

Mucchetti, G., M. Gatti, and E. Neviani. 1994. Electrical conductivity changes in milk caused by acidification: Determination factors. J. Dairy Sci. 77:940-944.

Park, Y. W. 1991. Interrelationships between somatic cell counts, electrical conductivity, bacteria counts, percent fat and protein in goat milk. Small Rumin. Res. 5:367-375.

Prentice, J. H. 1962. The conductivity of milk-The effect of the volume and degree of dispersion of the fat. J. Dairy Res. 29:131-139.

SAS Institute. 2002. SAS User's Guide: Statistics. Version 9.1. SAS Institute Inc., Cary. NC.

Yildiz, H., E. Kaygusuzoğlu, and H. Șimșek. 2006. Somatic cell count, electrical conductivity and biochemical parameters in mastitis milk in cows. Indian Vet. J. 83:498-500.

Ying, C. H., C. H.-B. Yang, and J.-T. Hsu. 2004. Relationship of somatic cell count, physical, chemical and enzymatic properties to the bacterial standard plate count in different breeds of dairy goats. Asian-australas. J. Anim. Sci. 17:554-559.

Zecconi, A., R. Piccinini, G. Giovannini, G. Casirani, and R. Panzeri. 2004. Clinical mastitis detection by on-line measurements of milk yield, electrical conductivity and milking duration in commercial dairy farms. Milchwissenschaft 59:240-244. 